\title{
Hematopoietic Stem Cell
} Transplantation Restores Naïve T-Cell Populations in Atm-Deficient Mice and in Preemptively Treated Patients With Ataxia-Telangiectasia

\section{OPEN ACCESS}

Edited by:

Sudhir Gupta,

University of California, Irvine,

United States

Reviewed by:

Alain Fischer

Institut National de la Santé et de la

Recherche Médicale

(INSERM), France

Neena Kapoor

Children's Hospital of Los Angeles,

United States

*Correspondence:

Ruth Duecker

ruthpia.duecker@kgu.de

Specialty section:

This article was submitted to

Primary Immunodeficiencies,

a section of the journal

Frontiers in Immunology

Received: 14 May 2019 Accepted: 13 November 2019 Published: 27 November 2019

Citation:

Duecker R, Baer PC, Buecker A, Huenecke S, Pfeffermann L-M, Modlich U, Bakhtiar S, Bader P,

Zielen S and Schubert R (2019)

Hematopoietic Stem Cell

Transplantation Restores Naive T-Cell

Populations in Atm-Deficient Mice and in Preemptively Treated Patients With

Ataxia-Telangiectasia.

Front. Immunol. 10:2785.

doi: 10.3389/fimmu.2019.02785
Ruth Duecker ${ }^{1 *}$, Patrick C. Baer ${ }^{2}$, Aileen Buecker ${ }^{1}$, Sabine Huenecke ${ }^{3}$, Lisa-Marie Pfeffermann ${ }^{3}$, Ute Modlich ${ }^{4}$, Shahrzad Bakhtiar ${ }^{3}$, Peter Bader ${ }^{3}$, Stefan Zielen ${ }^{1}$ and Ralf Schubert ${ }^{1}$

${ }^{1}$ Division for Allergy, Pneumology and Cystic Fibrosis, Department for Children and Adolescence, Goethe-University, Frankfurt, Germany, ${ }^{2}$ Division of Nephrology, Department of Internal Medicine III, Goethe-University, Frankfurt, Germany, ${ }^{3}$ Division for Stem Cell Transplantation and Immunology, Department for Children and Adolescents, University Hospital Frankfurt, Frankfurt, Germany, ${ }^{4}$ Research Group for Gene Modification in Stem Cells, Division of Veterinary Medicine, Paul-Ehrlich-Institute, Langen, Germany

Background: Ataxia-telangiectasia $(\mathrm{A}-\mathrm{T})$ is a multisystem disorder with progressive cerebellar ataxia, immunodeficiency, chromosomal instability, and increased cancer susceptibility. Cellular immunodeficiency is based on naïve $\mathrm{CD}^{+}{ }^{+}$and $\mathrm{CD} 8^{+} \mathrm{T}^{-}$-cell lymphopenia. Hematopoietic stem cell transplantation (HSCT) offers a potential to cure immunodeficiency and cancer due to restoration of the lymphopoietic system. The aim of this investigation was to analyze the effect of HSCT on naiive $\mathrm{CD}^{+}{ }^{+}$as well as $\mathrm{CD}^{+}$ T-cell numbers in A-T.

Methods: We analyzed total numbers of peripheral naïve $\left(C D 45 R A^{+} C D 62 L^{+}\right)$and memory $\left(\mathrm{CD} 45 \mathrm{RO}^{+} \mathrm{CD}_{2} \mathrm{~L}^{-}\right) \mathrm{CD}^{+}$and $\mathrm{CD}^{+}$T-cells of $32 \mathrm{~A}-\mathrm{T}$ patients. Naïve (CD62L high ${ }^{\mathrm{CD}} 44^{\text {low) }}$ ) and memory (CD62 $\mathrm{L}^{\text {low }} \mathrm{CD} 44^{\text {high }}$ ) T-cells were also measured in Atm-deficient mice before and after HSCT with GFP-expressing bone marrow derived hematopoietic stem cells. In addition, we analyzed T-cells in the peripheral blood of two A-T patients after HLA-identic allogeneic HSCT.

Results: Like in humans, naïve $\mathrm{CD}^{+}$as well as naive $\mathrm{CD} 8^{+}$lymphocytes were decreased in Atm-deficient mice. HSCT significantly inhibited thymic lymphomas and increased survival time in these animals. Donor cell chimerism increased up to more than 50\% 6 months after HSCT accompanied by a significant increase of naïve CD4 and CD8 T-cell subpopulations, but not of memory T-cells. This finding was also identified in the blood of the A-T patients after HSCT.

Conclusion: HSCT seems to be a feasible strategy to overcome immunodeficiency and might be a conceivable strategy to avoid T-cell driven cancer in A-T at higher risk for malignancy. Naïve CD4 and CD8 T-cells counts are suitable markers for monitoring immune reconstitution post-HSCT. However, risks and benefits of HSCT in A-T have to be properly weighted.

Keywords: ataxia telangiectasia, stem cell transplantation, ATM, immune deficiency, CD45RA naïve lymphocytes 


\section{INTRODUCTION}

Ataxia-telangiectasia (A-T) is a rare devastating human recessive disorder caused by mutations in the gene coding for ATM (Ataxia Telangiectasia Mutated) $(1,2)$. The consequence of compound heterozygous or homozygous mutations is a pleomorphic disease characterized by progressive neurodegeneration with cerebellar ataxia, immunodeficiency, severe lung disease, chromosomal instability and elevated risk of malignancies $(3,4)$. Recurrent infections contribute to the lung disease leading to bronchiectasis and pneumonias and ultimately respiratory failure $(5,6)$. Lung failure and cancer are the main causes for morbidity and mortality in A-T (7). The ATM gene plays an essential role in cell cycle control and repair of DNA damage after DNA double strand breaks and inactivation of ATM is responsible for T-cell lymphopenia and increased risk for T-cell lymphoma/leukemia (8-10).

Immunodeficiency in A-T is heterogeneous and involves both humoral and cellular immune response. Humoral immunodeficiency goes along with reduction of $\mathrm{IgG}_{2}, \operatorname{IgA}$, and $\operatorname{IgE}(11,12)$. Moreover, patients fail in the production of $\operatorname{IgG}$ antibodies to pneumococcal polysaccharides leading to recurrent infections, severe bronchiectasis and to pulmonary failure (13).

Cellular immunodeficiency is based on thymic hypoplasia and T-cell lymphopenia with selective reduction of circulating naïve $\left(\mathrm{CD} 45 \mathrm{RA}^{+}\right) \mathrm{CD}^{+} \mathrm{T}$-cells as well as naïve $\mathrm{CD} 8^{+} \mathrm{T}$ cells, but not of memory $\left(\mathrm{CD}_{4} 5 \mathrm{RO}^{+}\right) \mathrm{T}$-cells $(14,15)$. The proportion of $\mathrm{T}$ lymphocytes with $\alpha / \beta$ protein chains of the TCR, which develop to CD4-positive T helper cells or CD8 positive cytotoxic T-cells in the thymus, is significantly reduced in A-T patients and shifted to $\gamma / \delta$ protein chain bearing TCRs $(16,17)$. In addition, low TREC and KREC copies suggestive of abnormal $\mathrm{T}$ and $\mathrm{B}$ cell neogenesis has been described (18). Consistent with a causal role of ATM-deficiency in these abnormal recombination events, Atm-deficient mice die in high proportion from thymic lymphomas that involve recombination-activating-gene-dependent translocations of the TCR $\alpha$ and TCR $\delta$ locus (19). Atm deficient mice show a decrease in absolute numbers of thymocytes due to an aberrant T-cell development. The frequency of $\mathrm{CD} 4^{+} / \mathrm{CD} 8^{+}$double-positive cells and $\mathrm{CD} 4^{--/} \mathrm{CD} 8^{-}$double negative cells is increased in the thymus of the Atm-deficient mice compared to healthy control mice, whereas the number of mature CD4 and CD8 singlepositive cells is significantly reduced (19-21).

Restoration of the immune system by hematopoietic stem cell transplantation (HSCT), which is already used in other genetic instability syndromes, significantly inhibited tumorigenesis, improved immunity, weight gain, and fitness of Atm deficient mice (22-24). Recently, an A-T patient has been transplanted with an HLA identical sibling donor after a mild conditioning

\footnotetext{
Abbreviations: A-T, ataxia-telangiectasia; ATM, ataxia telangiectasia mutated; BMDC, bone marrow derived cells; BMT, bone marrow transplantation; CD, cluster of differentiation; CP, cyclophosphamide; DNA, deoxyribonucleic acid; EDTA, ethylenediaminetetraacetic acid; GFP, green fluorescent protein; HLA, human leukocyte antigen; HSCT, hematopoietic stem cell transplantation; Ig, immunoglobulin; KREC, kappa-deleting recombination excision circle; TCR, T-cell receptor; TREC, T-cell receptor excision circle.
}

regimen prior to any sign of a hematologic malignancy at the age of 5 years (25). HSCT corrected T-cell lymphopenia by expansion of $\mathrm{CD}_{4}^{+}$and $\mathrm{CD}^{+}{ }^{+}$-cells, and $\mathrm{CD} 19^{+}$cells. Post-HSCT, an increase in serum immunoglobulins, particularly $\operatorname{IgA}$ and $\operatorname{IgG} 2$ concentrations to normal ranges as well as in pneumococcal vaccine antibodies was identified. Interestingly, numbers of naïve $\mathrm{CD}^{+} \mathrm{T}$-cell rather than of memory $\mathrm{CD} 4^{+}$cells were increased comparing pre- and post-HSCT.

This prompted us to take a closer look at the naïve T-cell population in regard of HSCT in A-T. From bedside to bench and back again, in this article we aimed to examine (1) whether lymphopenia of naïve T-cells is also reflected in the peripheral blood of Atm-deficient mice, the mouse model of the human disease A-T, (2) to what extend HSCT does influence distribution of naïve $\left(\mathrm{CD} 62 \mathrm{~L}^{\text {high }} / \mathrm{CD} 44^{\text {low }}\right)$ and memory (CD62 $\left.\mathrm{L}^{\text {low }} / \mathrm{CD} 44^{\text {high }}\right) \mathrm{CD} 4^{+}$and $\mathrm{CD} 8^{+}$T-cells in these mice and (3) compare the results to the immunological findings of the transplanted A-T patients by our group (25).

Our results demonstrated that the Atm-deficient mouse highly reflects the human immunological T-cell phenotype and that HSCT restores naïve rather than memory CD4 and CD8 T-cell subsets in A-T.

\section{MATERIALS AND METHODS}

\section{Patients}

We analyzed all available records of lymphocytes especially naïve $\left(\mathrm{CD} 45 \mathrm{RA}^{+} \mathrm{CD}_{62} \mathrm{~L}^{+}\right)$and memory $\left(\mathrm{CD} 45 \mathrm{RO}^{+} \mathrm{CD} 62 \mathrm{~L}^{+}\right) \mathrm{CD}^{+}$ and $\mathrm{CD}^{+}$T-cells of 32 patients with classic A-T (aged 2-27 years, 21 of the patients were male), who were in the care of the Frankfurt University Hospital from 2008 to 2014. The examination of these patients was approved by the ethical board of the Faculty of Medicine at the J.W. Goethe University of Frankfurt/Main. The trials were registered at ClinicalTrials.gov 2012 (Susceptibility to infections in ataxia telangiectasia; NCT02345135) and 2017 (Susceptibility to Infections, tumor risk and liver disease in patients with ataxia telangiectasia; NCT03357978). Two patients were treated preemptively by alloHSCT to restore immunity and to prevent malignancy. Both patients received a reduced intensity and reduced toxicity conditioning regimen using fludarabine and cyclophosphamide and anti-thymocyte globulin. Patients received alloHSCT from a matched sibling donor. Patient one is currently 7 years postminimal intensive conditioned alloHSCT with fully restored immunity and data on HSCT in patient 1 is extensively discussed by Bakhtiar et al. (25). A-T related neurological impairment is slowly progressive. On long term follow-up, there are no transplant-related toxicity and no signs of acute or chronic GvHD. Patient 2 was a 5-years old boy with recurrent infections, who received also minimal intensive conditioning with fludarabin and cyclophosphamide and serotherapy which was tolerated well. Bone marrow of a matched sibling was the source of stem cells. Rapid and stable engraftment (day 10) as well as early immune reconstitution were observed. Patient developed an intermittent viral reactivation (BK-virus and metapneumovirus) causing an episode of pulmonary hypertension which was treated with oral medication. On latest 
follow-up (1.5 years post-alloHSCT), patient does not show any signs of organ toxicity and/or GvHD. The blood samples were analyzed for lymphocyte phenotyping 1- and 2-years posttransplantation, respectively.

\section{Animals}

Atm-deficient mice [Atm ${ }^{\text {tml(Atm)Awb }} ; 8-10$ weeks old], in a $129 \mathrm{~S} 6 / \mathrm{SvEv}$ background, were used as the animal model (26). The animal studies were performed according to the protocols approved by the German Animal Subjects Committee (Gen. Nr. $\mathrm{FK} / 1034)$. Mice were housed in individually ventilated plastic cages on a 12-h light/12-h dark cycle with access to food and water ad libitum until harvest. B6/EGFP mice (Jackson Laboratory, ME, USA) were crossed with Atm-heterozygous mice and the offspring were used for donor mice (27). Mice were checked 5 days/week and sacrificed when thymic lymphomas emerged. Weight was taken once a week during the observation period of 6 months post-transplantation.

\section{Bone Marrow Transplantation in Atm-Deficient Mice}

Atm-deficient mice received $0.125 \mathrm{mg} / \mathrm{mL}$ anti CD4 (clone GK1.5, BioLegend Cat\# 100435, RRID:AB_2075571) and 0.125 $\mathrm{mg} / \mathrm{mL}$ anti CD8 (clone 53-6.7, BioLegend Cat\# 100735, RRID:AB_2075237) monoclonal antibody, 7 days before bone marrow transplantation (BMT) and a second dose of each antibody in combination with cyclophosphamide (CP, $80 \mathrm{ng} / \mathrm{mL}$, Endoxan, Baxter, Unterschleißheim, Germany) 1 day before BMT as non-myeloablative conditioning. $5 \times 10^{6}$ bone marrow donor cells (BMDCs) were sterilely harvested from 129 S6/SvEv GFP-transfected wild-type mice and were then injected intravenously into conditioned recipients $(22,24)$. Grafting of ATM-competent $\mathrm{GFP}^{+}$bone marrow-derived donor cells was traced in the peripheral blood of Atm-deficient mice over the time, 6,12 , and 24 weeks post-transplantation.

\section{Peripheral Blood Cell Counts}

Mice were bled from the vena facialis into EDTA-coated tubes. Blood cell counts were determined using a Hemavet 950 analyzer (Drew Scientific Inc., Miami Lakes, FL, USA).

\section{Flow Cytometry}

Blood samples from Atm-deficient mice were taken at 6, 12, and 24 weeks post-transplantation and untreated wild-type mice by tapping the vena facialis in the lower jaw area after venous congestion of Atm-deficient mice. Whole blood samples containing EDTA were first blocked with anti-CD16/32 antibody (BD Biosciences Cat\# 560804, RRID:AB_2034004) and then surface stained for anti-CD3-BV450 (BD Biosciences Cat\# 561389, RRID:AB_10679120), anti-CD4-PerCP (BD Biosciences Cat\# 553052, RRID:AB_394587), and CD8-PE-Cy7 (BD Biosciences Cat\# 552877, RRID:AB_394506) and analyzed for GFP expression. The CD4 and CD8 T-cell subset were further characterized for the expression for CD44 and CD62L (BD Biosciences Cat\# 559250, RRID:AB_398661 and BD Biosciences Cat\# 553151, RRID:AB_394666). After staining, erythrocytes were lyzed with FACS lysing solution (BD, Heidelberg, Germany) and washed with phosphate buffered saline (PBS). For analyzing, 10.000 events were recorded using a FACSVerse flow cytometer (BD, Heidelberg, Germany). The data were evaluated using FACSuite software.

Naïve and memory T-cells within patient blood were analyzed as follows: two tubes with $100 \mu \mathrm{l}$ of PBS were labeled with fluorochrome-coupled antibodies against CD45RAFITC (ALB11), CD45RO-PE (UCHL1), CD3-ECD (UCHT1), CD62L-PC5 (DREG56), and CD4- (T4) or CD8-PC7 (T8). All reagents are purchased from Beckman Coulter ${ }^{\circledR}$ Immunotech (Marseilles, France). Absolute cell counts are calculated from the percentage values using a dual-platform approach. Flow-Set ${ }^{\mathrm{TM}}$ Fluorospheres served to set up the photo-multiplier tube values weekly. Stained Cyto-Comp ${ }^{\mathrm{TM}}$ Cells were applied to compensate the fluorescence overlap. The flow-cytometer optical alignment and the fluidic stability were tested daily using Flow-Check ${ }^{\mathrm{TM}}$ Fluorospheres and Immuno-Trol ${ }^{\mathrm{TM}}$ control cells were applied for verification.

\section{Statistics}

Statistical analyses were performed using GraphPad Prism 5.0 (GraphPad Prism, RRID:SCR_002798). Values are presented as the means ( \pm SEM) and were analyzed using the MannWhitney $U$-test or the Wilcoxon-Mann-Whitney test. For multiple comparisons, we used the one-way ANOVA with repeated measures. The survival times of the mice were used to generate Kaplan-Meier survival curves which were compared using the log-rank (Mantel-Cox) test. $P<0.05$ was considered as statistically significant.

\section{RESULTS}

\section{Immunophenotype Characteristics of Peripheral Blood Lymphocytes in A-T Patients and Atm-Deficient Mice}

Almost all patients (97\%) exhibited $\mathrm{CD}^{+}{ }^{+} \mathrm{CD} 45 \mathrm{RA}^{+} \mathrm{CD} 62 \mathrm{~L}^{+}$ T-cells below the 90th percentile, whereas most of the patient showed $\mathrm{CD}^{+}{ }^{+} \mathrm{CD} 45 \mathrm{RO}^{+} \mathrm{CD} 2 \mathrm{~L}^{+}$T-cells $(94 \%)$ within the 10 th and 90th percentile (Figures 1A,B). A similar distribution was found between $\mathrm{CD}^{+} \mathrm{CD} 45 \mathrm{RA}^{+} \mathrm{CD} 62 \mathrm{~L}^{+} \mathrm{T}$-cells $(88 \%)$ and $\mathrm{CD}^{+} \mathrm{CD}^{+} 5 \mathrm{RO}^{+} \mathrm{CD} 2 \mathrm{~L}^{+} \mathrm{T}$ cells (97\%) (Figures 1C,D). Overall, neither the $\mathrm{CD}^{+} \mathrm{T}$-cell numbers nor $\mathrm{CD}^{+} \mathrm{T}$-cell numbers indicated a tendency for progressive loss of total naïve T-lymphocytes.

In the serum of 8-10 week-old Atm-deficient mice we found significantly reduced total lymphocyte numbers, $\mathrm{CD} 3^{+}, \mathrm{CD} 4^{+}$ and $\mathrm{CD}^{+}$cells (total lymphocytes: $\mathrm{Atm}^{-/-} 3.89 \pm 0.57 \times$ $10^{3}$ cells $/ \mu \mathrm{l}, \mathrm{Atm}^{+/+} 5.76 \pm 0.67 \times 10^{3}$ cells $/ \mu \mathrm{l}, P<0.05$;

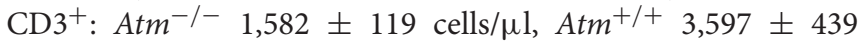
cells/ $\mu \mathrm{l}, P<0.01 ; \mathrm{CD}^{+}: \mathrm{Atm}^{-/-} 1,234 \pm 82.1$ cells $/ \mu \mathrm{l}$, $\mathrm{Atm}^{+/+} 3,111 \pm 297$ cells $/ \mu \mathrm{l}, \mathrm{P}<0.001 ; \mathrm{CD}^{+}: \mathrm{Atm}^{-/-} 385$ \pm 23.9 cells $/ \mu \mathrm{l}, \mathrm{Atm}^{+/+} 957 \pm 107$ cells $\left./ \mu \mathrm{l}, P<0.001\right)$ in comparison to wild-type mice (Figures 2A-E,I), whereas no differences in $\mathrm{B}$ cell and NK cell numbers were found. The analysis of T-cell subsets from Atm-deficient mice revealed a significant lower number of naïve $\mathrm{CD} 62 \mathrm{~L}^{\text {high }} / \mathrm{CD} 44^{\text {low }} / \mathrm{CD} 4^{+}$ 


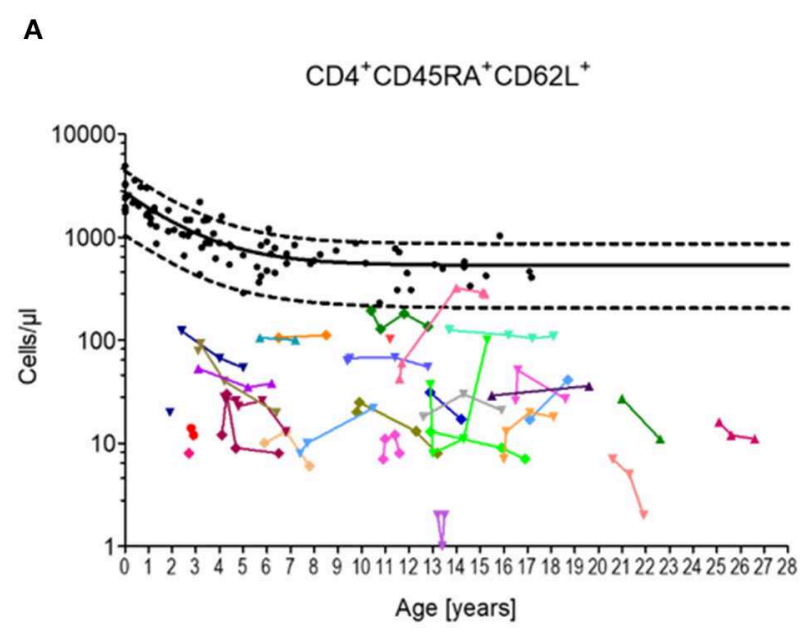

C

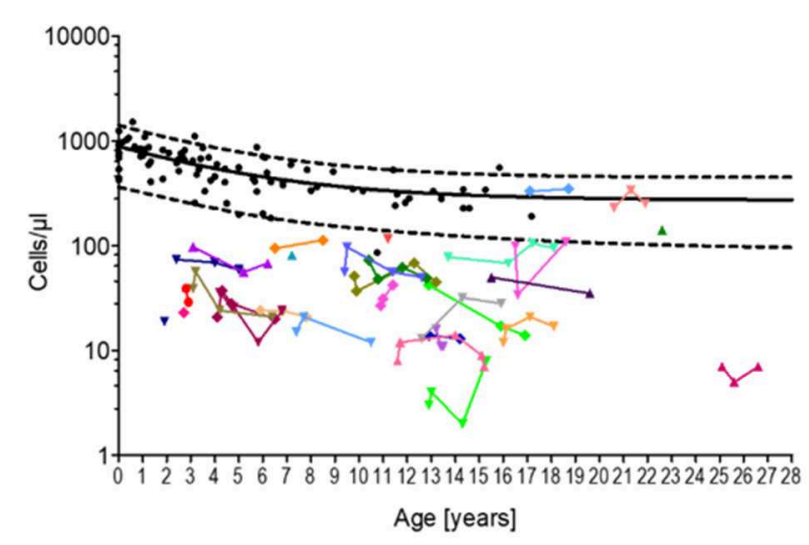

B

$\mathrm{CD}^{+}{ }^{+} \mathrm{CD} 45 \mathrm{RO}^{+} \mathrm{CD} 2 \mathrm{~L}^{+}$

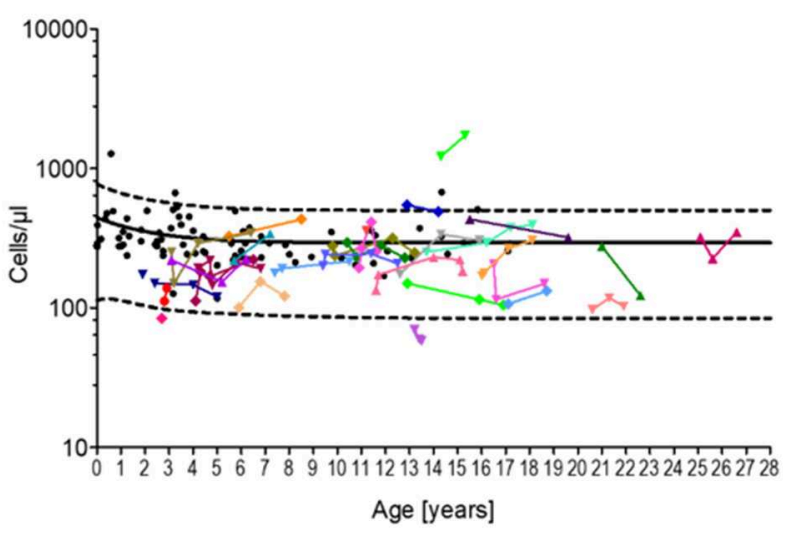

D

$\mathrm{CD} 8{ }^{+} \mathrm{CD} 45 \mathrm{RO}^{+} \mathrm{CD} 62 \mathrm{~L}^{+}$

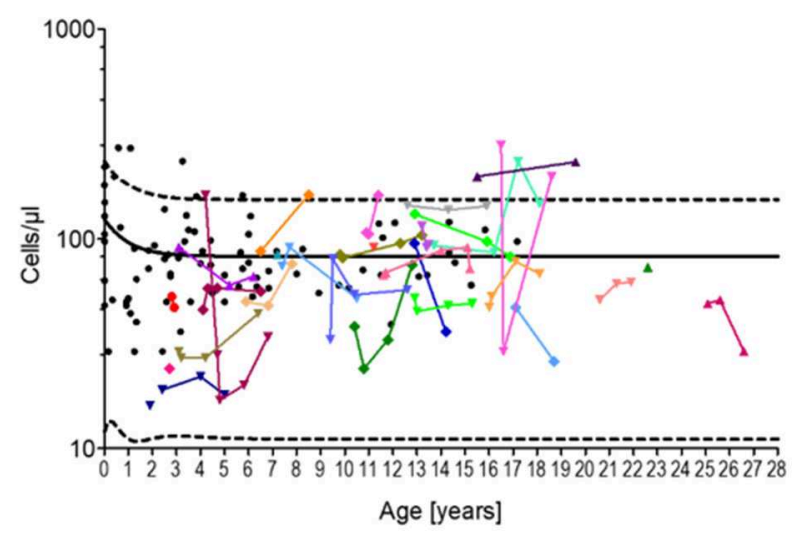

FIGURE 1 | Cellular immune constitution in patients with Ataxia Telangiectasia compared to healthy controls. Blood samples of 32 A-T patients (colored dots) were

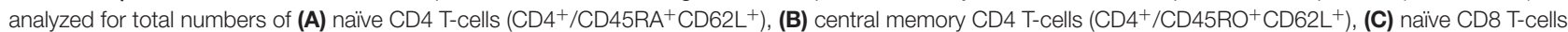
$\left(\mathrm{CD}^{+} / \mathrm{CD} 45 \mathrm{RA}^{+} \mathrm{CD} 2 \mathrm{~L}^{+}\right)$, and $(\mathbf{D})$ central memory CD8 T-cells $\left(\mathrm{CD} 8^{+} / \mathrm{CD} 45 \mathrm{RO}^{+} \mathrm{CD} 2 \mathrm{~L}^{+}\right)$in comparison to healthy sex- and age-matched controls $($black dots, $n=$ 20). Black line and black dashed lines represents the 50th, the 5th and 95th percentile of the standard values, respectively.

and $\mathrm{CD} 62 \mathrm{~L}^{\mathrm{high}} / \mathrm{CD} 44^{\text {low }} / \mathrm{CD} 8^{+}$T-cells $\left(\mathrm{CD} 4^{+}: \mathrm{Atm}^{-/-} 989\right.$ \pm 115 cells $/ \mu \mathrm{l}$, Atm $^{+/+} 2,461 \pm 355$ cells $/ \mu 1, P<0.001$;

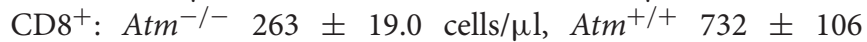
cells/ $\mu 1, P<0.01)$ compared to wild-type mice, whereas no differences in memory $\mathrm{CD} 62 \mathrm{~L}^{\text {low }} / \mathrm{CD} 44^{\text {high }}$ and double positive CD62 $\mathrm{L}^{\text {high }} / \mathrm{CD} 44^{\text {high }} \mathrm{T}$-cell subsets could be detected (Figures 2F-H,J-L).

\section{Prolonged Life Span and Restoration of Cellular T-Cell Immunity After HSCT in Atm-Deficient Mice}

HSCT significantly prolonged the life span of the Atm deficient mice compared to untreated Atm-deficient mice (Figure 3A). However, one mouse died because of the development of a thymic tumor. As expected, flow cytometric analysis showed a significant decrease in the absolute numbers of total lymphocytes, $\mathrm{CD}^{+}$T-cells, $\mathrm{CD}^{+}$helper T-cells, $\mathrm{CD}^{+}$cytotoxic T-cells and naïve $\mathrm{CD}^{+}$and $\mathrm{CD}^{+} \mathrm{T}$ cell subpopulations in the blood of Atm deficient mice compared to untreated wild-type mice (Figures 3B-E). Twenty-four weeks post-transplantation, a repopulation of total lymphocytes, $\mathrm{CD}^{+}{ }^{+}$and $\mathrm{CD}^{+}$and $\mathrm{CD}^{+}$cells was shown in Atm-deficient mice. Total lymphocytes increased from 61.7 to $100.6 \%$, $\mathrm{CD}^{+}$cells from 49.1 to $77.1 \%, \mathrm{CD}^{+}$T-cells from 48.3 to $83.8 \%$, and $\mathrm{CD}^{+}$T-cells from 50.5 to $77.9 \%$ the level of the wild-type mice (Figures 3A-E). Interestingly, the naïve CD62L $\mathrm{L}^{\text {high }} / \mathrm{CD} 44^{\text {low }} \mathrm{CD} 4$ and $\mathrm{CD} 8$ subsets in the blood samples of Atm-deficient mice were significantly increased after HSCT $\left(\mathrm{CD}^{+} / \mathrm{CD} 62 \mathrm{~L}^{\text {high }} / \mathrm{CD} 44^{\text {low }}\right.$ T-cells from 39.4 to $72.1 \%$; $\mathrm{CD}^{+} / \mathrm{CD} 2 \mathrm{~L}^{\text {high }} / \mathrm{CD} 44^{\text {low }} \mathrm{T}$-cells from 40.0 to $84.6 \%$ ), whereas 
A

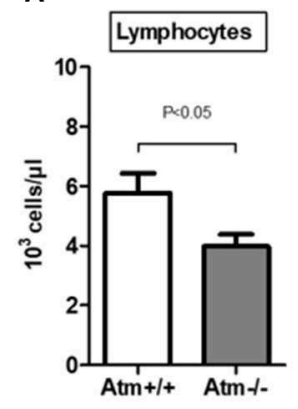

E

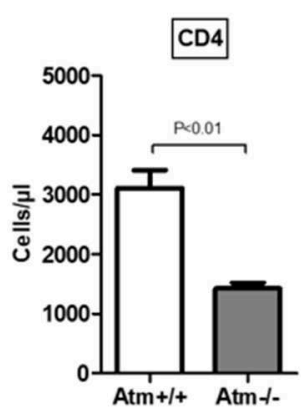

I

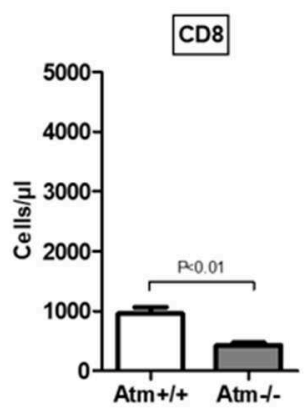

B

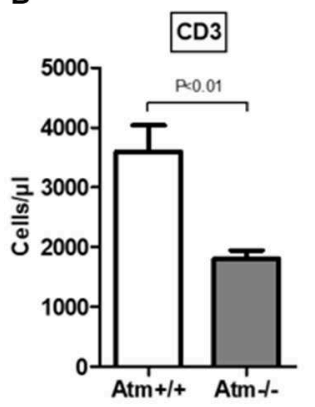

$\mathbf{F}$

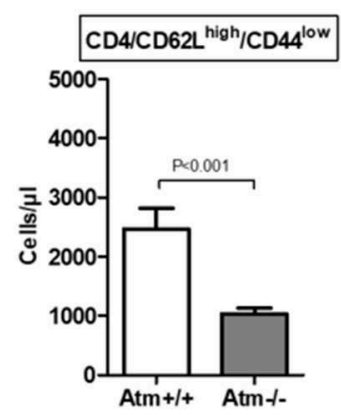

$\mathbf{J}$

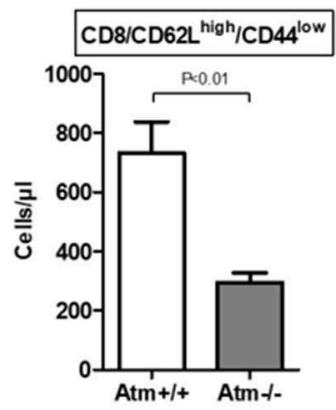

C

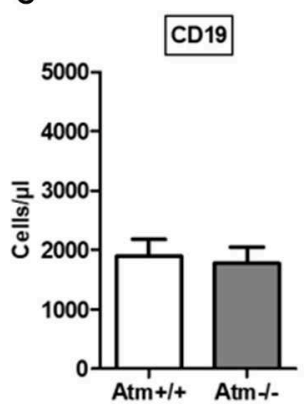

G

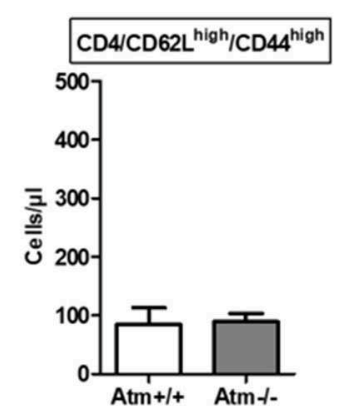

$\mathbf{K}$

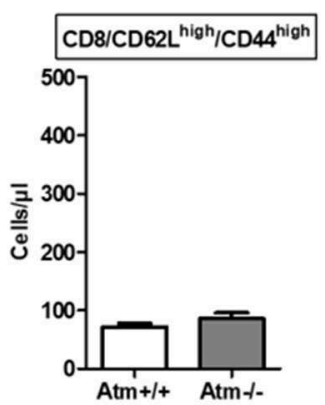

D

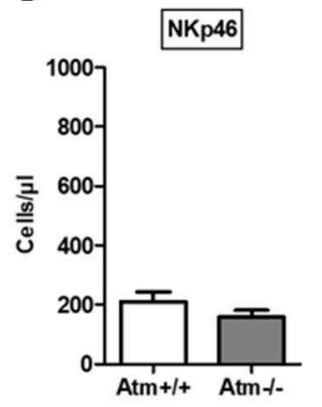

H

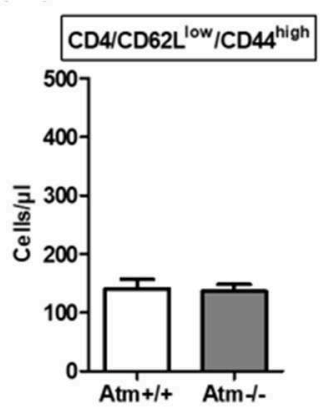

$\mathbf{L}$

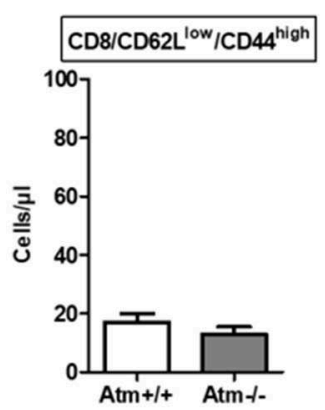

FIGURE 2 | Cellular immune constitution in Atm-deficient mice compared to wildtype mice. Total numbers of lymphocytes (A), CD3+ T-cells (B), CD19+ B-cells (C),

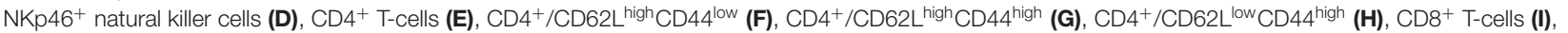
$\mathrm{CD}^{+} / \mathrm{CD} 2^{\mathrm{L}^{\text {high }}} \mathrm{CD} 44^{\text {low }} \mathbf{( J )}, \mathrm{CD}^{+} / \mathrm{CD} 62 \mathrm{~L}^{\text {high }} \mathrm{CD} 44^{\text {high }} \mathbf{( K )}, \mathrm{CD}^{+} / \mathrm{CD} 62 \mathrm{~L}^{\text {low }} \mathrm{CD} 44^{\text {high }} \mathbf{( L )}$ in the blood of 8-10 week-old Atm-deficient mice $(n=14) \mathrm{compared}$ to wild-type mice were analyzed $(n=8)$. Data are presented as mean \pm SEM.

no effect was detected for the memory CD62L $\mathrm{L}^{\text {low }} / \mathrm{CD} 44^{\text {high }}$ cell populations (Figures 3F-I).

\section{Increasing Donor Chimerism in Transplanted Atm-Deficient Mice}

Atm-deficient mice exhibited a mixed donor chimerism after HSCT with increasing numbers of $\mathrm{GFP}^{+}$donor lymphocytes, $\mathrm{CD}^{+}, \mathrm{CD}^{+}$, and $\mathrm{CD}^{+}$cells in the peripheral blood over the time (lymphocytes: 6 weeks $25.64 \pm 7.10 \%$ to 24 weeks $49.73 \pm 15.80 \%, P<0.01 ; \mathrm{CD}^{+}: 6$ weeks $29.41 \pm 5.41 \%$ to 6 months $49.27 \pm 13.70 \%, P<0.01 ; \mathrm{CD}^{+} / \mathrm{CD}^{+}: 6$ weeks $28.27 \pm 3.35 \%$ to 24 weeks $52.10 \pm 12.73 \%, P<$ $0.001 \mathrm{CD}^{+} / \mathrm{CD}^{+}: 6$ weeks $31.10 \pm 26.6 \%$ to 24 weeks $55.28 \pm 6.96 \%, P<0.001$ (Supplementary Figures 1A-D). The percentage of $\mathrm{GFP}^{+}$donor naïve $\mathrm{CD} 62 \mathrm{~L}^{\text {high }} / \mathrm{CD} 44^{\text {low }} / \mathrm{CD} 4^{+}$ and $\mathrm{CD} 62 \mathrm{~L}^{\text {high }} / \mathrm{CD} 44^{\text {low }} / \mathrm{CD} 8^{+}$T-cells followed the continuous increase during the observation period of 24 weeks $\left(\mathrm{CD}^{+}: 6\right.$ weeks $22.85 \pm 9.22 \%$ to 24 weeks $58.21 \pm 8.57 \%, P<0.001$; $\mathrm{CD}^{+}$: 6 weeks $24.72 \pm 14.37 \%$ to 24 weeks $57.27 \pm 6.65 \%$, $P<0.001)$. In contrast, percentage of $\mathrm{GFP}^{+}$donor memory (CD62L $\mathrm{L}^{\text {low }} / \mathrm{CD} 44^{\text {high }}$ ) T-cells reached their maximum 12 weeks after HSCT and did not further increase $\left(\mathrm{CD}^{+}: 6\right.$ weeks 20.65 
A

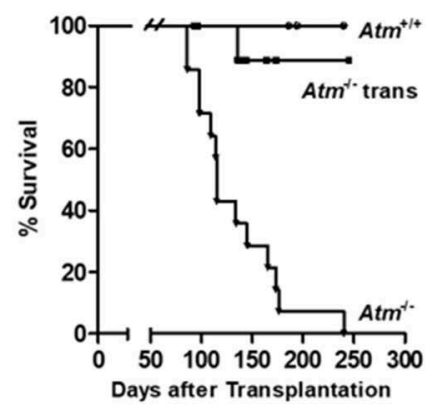

B

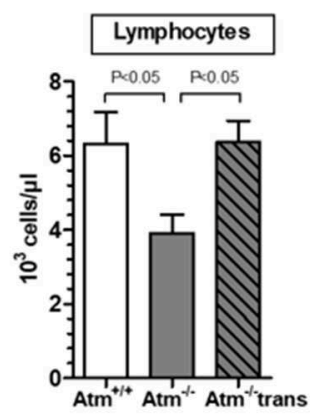

$\mathbf{F}$

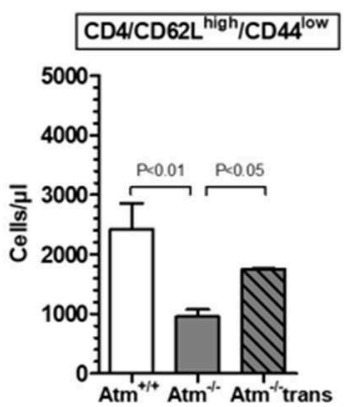

C

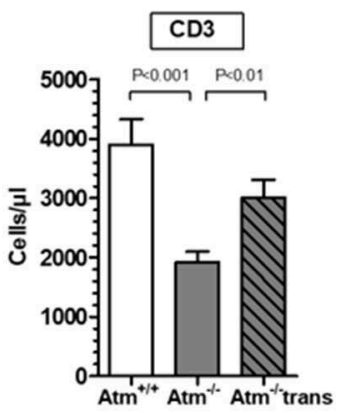

G

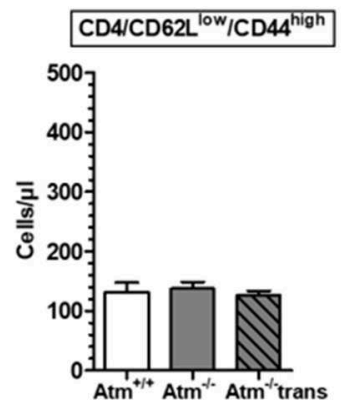

D

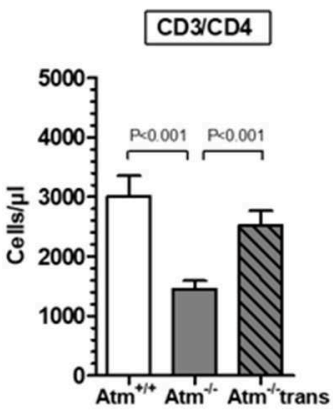

H

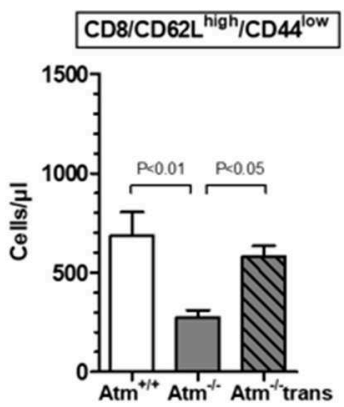

E

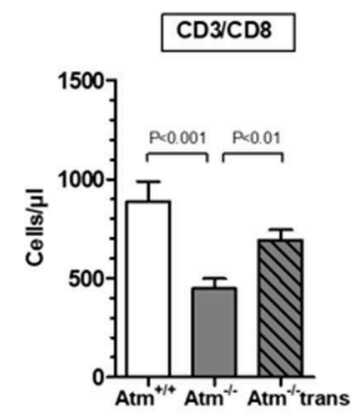

I

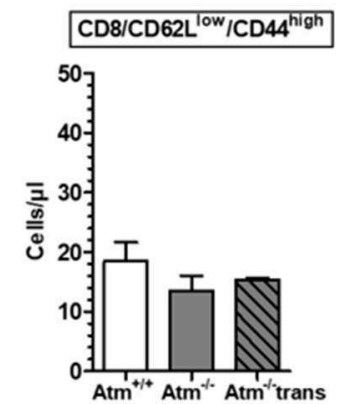

FIGURE 3 | Survival and chimerism in Atm-deficient mice after syngeneic hematopoietic SCT. Survival curves showed as Kaplan-Meier plots derived from Atm-/mice, after syngeneic HSCT (A). Total numbers of lymphocytes (B), CD3 ${ }^{+}$T-cells (C), CD3 ${ }^{+} / C D 4^{+}$helper T cells (D), CD3 ${ }^{+} / C D 8^{+}$cytotoxic T-cells (E),

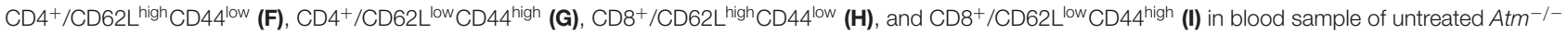
mice $(n=15)$, syngeneic transplanted Atm $^{-/-}$mice $(n=11)$ compared to untreated Atm $^{+/+}$mice $(n=12)$. Data are presented as mean \pm SEM.

$\pm 10.63 \%$ to 12 weeks $40.53 \pm 14.80 \%, P<0.01$; $\mathrm{CD}^{+}: 6$ weeks $6.67 \pm 14.91 \%$ to 12 weeks $46.31 \pm 32.38 \%, P<0.01$; Supplementary Figures 1E-H).

\section{Recovery of Immune Reactivity in an A-T Patient After HSCT}

Post-transplant peripheral blood samples were collected from two A-T patient 1 and 2 years after HLA-identical HSCT and analyzed for T-cells and T-cell subpopulations (Figure 4). We could show that the HSCT restored the diminished numbers of total lymphocytes, $\mathrm{CD}^{+}, \mathrm{CD}^{+}$, and $\mathrm{CD} 8^{+}$T-cells to normal ranges. In patient one, total lymphocytes increased by 1.4 -fold, $\mathrm{CD}^{+}$cells by 2.1 -fold, CD4 ${ }^{+}$T-cells by 2.7 -fold, and $\mathrm{CD} 8^{+}$ $\mathrm{T}$ cells by 2.3 -fold. In patient two, total lymphocytes increased by 4.6 -fold, $\mathrm{CD}^{+}$cells by 4.3 -fold, $\mathrm{CD} 4^{+} \mathrm{T}$-cells by 3.4 -fold, and $\mathrm{CD}^{+}$T-cells by 9.2 -fold (Figures $4 \mathrm{~A}-\mathrm{D}$ ). The increase of cells was most predominantly seen at the level of naïve $\left(\mathrm{CD} 4 \mathrm{RA}^{+}\right) \mathrm{CD}^{+}$and $\mathrm{CD}^{+} \mathrm{T}$ cell subsets in both patients. In patient one, $\mathrm{CD}^{+}{ }^{+} \mathrm{CD} 45 \mathrm{RA}^{+}$cells dramatically increased by 20.4-fold and $\mathrm{CD}^{+} \mathrm{CD}^{+} 5 \mathrm{RA}^{+}$cells by 4.9 -fold. In patient 

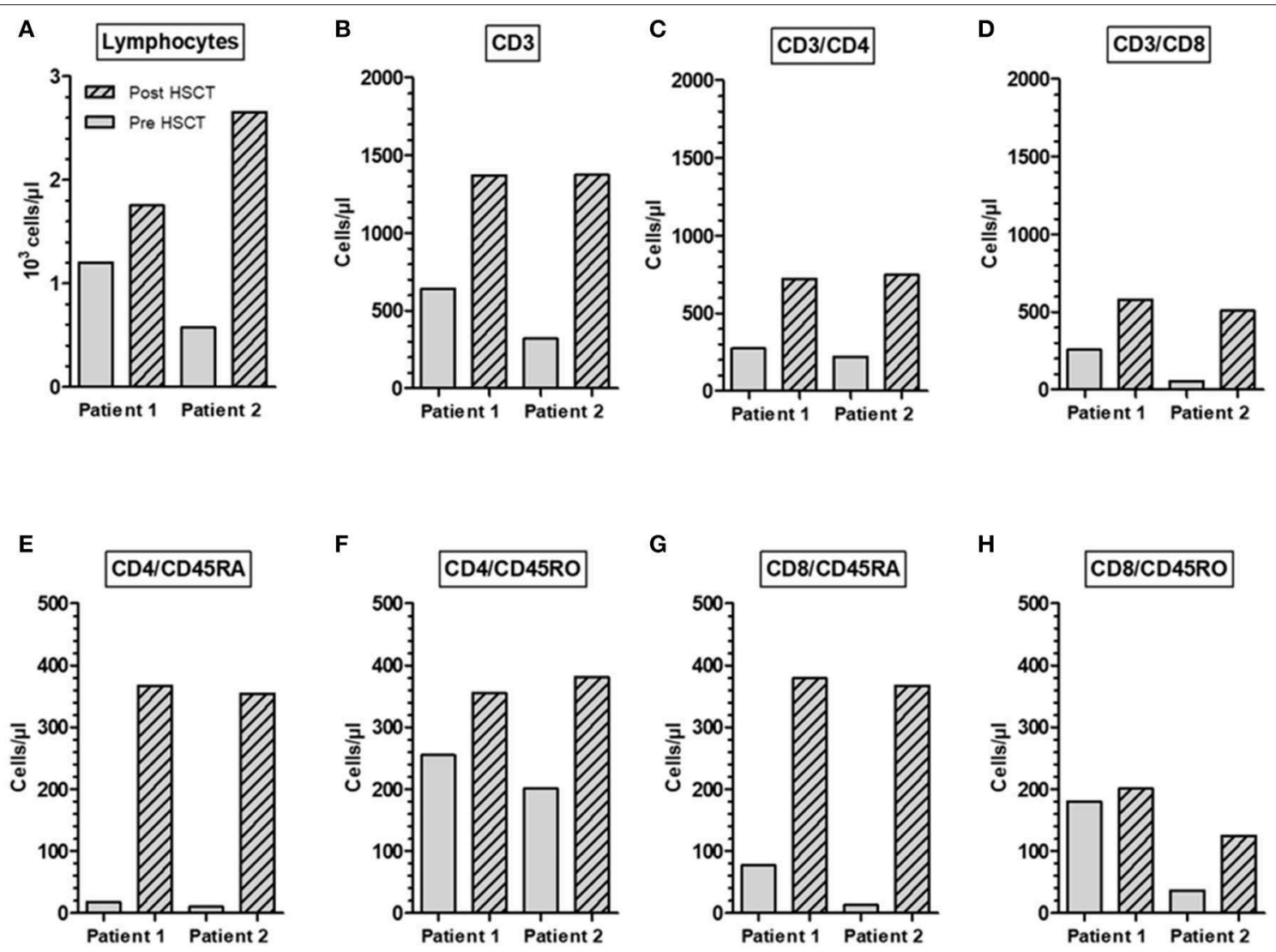

FIGURE 4 | Restoration of immune reconstitution in an A-T patient post-HSCT. Total numbers of lymphocytes (A), CD3 ${ }^{+}$(B), $\mathrm{CD}^{+} / \mathrm{CD} 4^{+}$(C), $\mathrm{CD}^{+} / \mathrm{CD} 8^{+}$(D), naiive CD45RA CD4 ${ }^{+}$and $C D 8^{+}$phenotype $\mathbf{( E , G ) ~ a n d ~ m e m o r y ~ C D 4 5 R O ~ C D 4 ~}{ }^{+}$and $\mathrm{CD} 8^{+}$phenotype (F,H). Samples were collected from two A-T patients 1 and 2 years after HLA-identical HSCT.

two, $\mathrm{CD}^{+}{ }^{+} \mathrm{CD} 45 \mathrm{RA}^{+}$cells increased by 35.4 -fold and $\mathrm{CD}{ }^{+}$ CD45RA ${ }^{+}$cells by 28.2-fold (Figures $4 \mathrm{E}-\mathbf{H}$ ).

\section{DISCUSSION}

At least two-thirds of patients with A-T suffer from immune deficiency affecting both cellular and humoral immunity $(6,18)$. Typically, low $\operatorname{IgA}$, low $\operatorname{IgG}_{2}$, defective polysaccharide antibody response, and lymphopenia involving $\mathrm{B}$ and $\mathrm{T}$ cells are described $(6,11,14)$. The immune deficiency is usually caused by defective double-strand break repair processes such as $\mathrm{V}(\mathrm{D}) \mathrm{J}$ recombination and class-switch recombination and decreased levels of $\mathrm{B}$ - and T-cells are accompanied by a limited antigen receptor repertoire (19-21). In the $\mathrm{T}$ cell population lymphopenia concerns both helper and cytotoxic T-cells due to a reduction of the naïve CD45RA subpopulations, whereas no reduction of cell numbers could be detected in memory CD45RO T-cells $(14,15)$.

The major interest of the present study was on the recovery of naïve CD4 as well as on naïve CD8 T-cell numbers during stem cell therapy. HSCT might be a pivotal approach to overcome immunodeficiency and T-cell-driven cancer in A-T.
Although earlier treatments of A-T patients often resulted in a fatal outcome and ended with the death of the patient, recent reports are more promising and might offer a new avenue for a therapeutic option for A-T $(25,28-31)$. The different outcomes reflect that conditioning regimen and donor selection are critical factors in the clinical setting of HSCT in A-T, and that transplantation should be performed early, during stages of limited disability. In addition, it is important to note, that HSCT had no effect on neurologic symptoms, growth failure, telangiectasia formation, or increased serum alpha fetoprotein and the risk and benefits of transplant therapy have to be properly weighted (29).

Due to the extreme cell loss in the naïve T-cell populations we hypothesize that HSCT can be able to fill this gap and balance the ratio between naïve and memory T-cells.

As expected, the phenotypic analysis of peripheral lymphocytes in our cohort of patients determined a significantly reduced number of naïve CD45RA T-cells but not memory CD45RO T-cells compared to age-appropriate default values. Our data give further evidence that naïve cell lymphopenia starts early in life and underlines the common understanding that the immune defect in $\mathrm{A}-\mathrm{T}$ is rarely progressive $(6,32)$. 
Since Paganelli et al. published loss of naïve CD4 T-cells in the year 1992 the question arose whether cell loss in A-T is restricted to the naïve cell populations (14). Naïve CD4 and CD8 T-cells expressing the CD45RA antigen are released from the thymus after several selection and maturation processes $(33,34)$. They hardly divide and their numbers remain relatively stable after the onset of thymic atrophy at puberty (33). After antigen experience, naïve cells become central or effector memory $\mathrm{T}$ cells gain expression of CD45RO and lose expression of CD45RA (35). Unlike naïve T cells memory cells undergo intermittent cell division and numbers of memory $\mathrm{T}$-cells increase progressively with age $(33,36)$.

In $\mathrm{A}-\mathrm{T}$ a reduced ability in hematopoietic stem cells division already during the development of lymphocyte progenitor cells in the bone marrow has been proposed. Due to the ATM deficiency and the impaired reparation of DNA strand breaks, oxidative stress in hematopoietic stem cells accumulates, and the hematopoietic stem cells lose the ability to self-renew $(20,21,37)$. In the further developmental process, Giovannetti et al. described a limited maturation of lymphocytes in the thymus which was measured on existing T-cell receptor excision rings (TRECs) to determine the number of mature lymphocytes in the thymus (38). Micheli et al. were able to demonstrate that the reduced heterogeneity of T-lymphocytes in the ATM deficiency disorder is associated with a decreased diversity of the $\alpha / \beta$ T-cells (39). Matei et al. further described that the ATM protein has a central role in the development of the protein $\kappa$ chains of the T-cell receptor with respect to the recognition and repair of double strand breaks in the $\mathrm{V}(\mathrm{D}) \mathrm{J}$ recombination. A lack of ATM leads to impaired T-cell maturation and accumulation of immature cells in the thymus (40). Underlying its genomic instability, the $\mathrm{T}$ cell receptor $\alpha$ locus causes arrest of T-cell maturation in the double positive phase (41). Noteworthy, the adequate response to reactive oxygen species in the thymus is impaired in the absence of a functional ATM protein (42). The implication is herein an aberrant $\mathrm{V}(\mathrm{D}) \mathrm{J}$ recombination during TCR development with regard to an interchromosomal recombination between TCR $\beta$ and TCR $\gamma$ genes. Overall, the impaired development of CD45RApositive cells can be attributed to defects in the formation of progenitor cells followed by the altered maturation of T-cells released from the thymus.

To investigate whether the numbers of naïve CD4 and CD8 T-cells could serve as markers for successful HSCT the aim of the study was to take a closer look at the naïve T-cell population during HSCT in A-T. Because of limited data derived from A-T patients with HSCT, in our study we investigated naïve T-cells in the Atm-deficient mouse model. In Atm-deficient mice, restoration of the immune system and inhibition of tumorigenesis have been shown after HSCT (22, 24). However, one has to keep in mind that the naïve T-cell pool differs between mice and men (34). In this regard, it is important to note, that in mice the corresponding populations of naïve CD45RA and memory CD45RO cells are identified as CD62LhighCD44low cells and $\mathrm{CD}_{2} \mathrm{~L}^{\text {low }} \mathrm{CD} 44^{\text {high }}$ cells, respectively $(35,43,44)$.

Although loss of T-cells is well-described in several Atmdeficient mouse models, to our knowledge data about naïve CD4 or CD8 T-cells in these animals does not exist (26, 45-47). Our phenotyping analysis of the peripheral blood cell populations from Atm $^{\text {tml(Atm)Awb }}$ mice revealed decreased numbers of CD4 as well CD8 T cells in accordance with earlier investigations $(24,26)$. Similar to human, lymphopenia in the Atm-deficient mouse is due to the loss of naïve (CD62 $\left.\mathrm{L}^{\text {high }} \mathrm{CD} 44^{\text {low }}\right) \mathrm{CD} 4$ and CD8 T cells whereas no differences could be found for memory T-cells. Based on this data the Atm-deficient mouse provides a pivotal model to study numbers of naïve CD4 and CD8 T-cells during HSCT. As expected HSCT combined with a clinically relevant non-myeloablative host-conditioning regimen inhibited development of thymic lymphomas prolonging the lifespan of Atm-deficient mice through the restoration of the CD4 as well as the CD8 T-lymphocyte populations over time (24). Interestingly, naïve CD4 and CD8 cells showed a steady increase in cell numbers until 24 weeks after HSCT, whereas numbers of memory T-cells rise and then fall off again. Thus, HSCT resulted in a significant increase in the naive, but not memory T-cells and balanced this T-cell ratio in Atm-deficient mice.

Post-transplant renewal of the T-cell immune system is a slow process, which can be divided in the clonal expansion of donor grafts- and residual host-derived mature hematopoietic cells and the de novo generation of lymphoid and myeloid linages from the transferred hematopoietic stem cells (48-50). Following this line, expansion of both donor and host-derived cells reflect the cellular status 12 weeks after HSCT in our mouse model and explains the further increase in naïve cells after 24 weeks due to the de novo generated naïve $\mathrm{T}$-cell released from the host's thymus.

Translation from the Atm-deficient mouse into A-T patients confirmed our assumption that HSCT fills this gap of naïve Tcells in A-T. Both A-T patients were transplanted preemptively which is defined as transplantation before any malignancies occurred. Both transplanted patients developed an initial mixed donor chimerism, increasing to over $90 \%$ of donor origin over time in their $\mathrm{CD}^{+}$subset (25). A closer look at the absolute T-cell numbers before and after HSCT showed that increase in Tcell numbers was mainly based on the increase of naïve CD4 and CD8 cells and to lesser extend of memory T cell phenotypes and therefore, emphasized naïve T-cells could function as a pivotal biomarker for a successful HSCT in A-T. In this context it is important to note that our study has potential limitations due to the missing validation of TREC and CD31 coexpression by $\mathrm{CD}_{45 \mathrm{RA}^{+}} \mathrm{T}$-cells which would give further information about thymus-derived T-cells.

Although functionality of these naïve T-cells was not directly tested in our study, it can be reasonably concluded that these cells overcome immunodeficiency because of the donor's character. In fact, HSCT corrected cellular as well as humoral immune functions and there was a complete remission of skin and joint granulomas in this A-T patient $(25,51)$. In addition, data derived from Atm-deficient mice clearly showed inhibited development of thymic lymphomas and prolonged lifespan of the animals (24). Therefore, analysis of naïve CD4 and CD8 cells provide a picture of the immune reconstitution process in $\mathrm{A}-\mathrm{T}$ patients and other patients with chromosomal 
instability and/or immunodeficiency syndromes and seems to be relevant markers for the measure of quality of the HSCT (52).

\section{DATA AVAILABILITY STATEMENT}

The datasets generated for this study are available on request to the corresponding author.

\section{ETHICS STATEMENT}

The examination of these patients was approved by the ethical board of the Faculty of Medicine at the J.W. Goethe University of Frankfurt/Main. The trials were registered at ClinicalTrials.gov 2012 (Susceptibility to infections in ataxia telangiectasia; NCT02345135) and 2017 (Susceptibility to Infections, tumor risk and liver disease in patients with ataxia telangiectasia; NCT03357978). Written informed consent to participate in this study was provided by the participants' legal guardian/next of kin. This animal study was reviewed and approved by German Animal Subjects Committee (Gen. Nr. FK/1034).

\section{AUTHOR CONTRIBUTIONS}

$\mathrm{RD}$ and RS conceptualized and designed the study and wrote the manuscript. $\mathrm{RD}, \mathrm{AB}, \mathrm{SH}, \mathrm{L}-\mathrm{MP}, \mathrm{UM}, \mathrm{SB}$, and PCB helped with acquisition of data. RD, SB, RS, PB,

\section{REFERENCES}

1. Rothblum-Oviatt C, Wright J, Lefton-Greif MA, McGrath-Morrow SA, Crawford TO, Lederman HM. Ataxia telangiectasia. A review. Orphanet J Rare Dis. (2016) 11:159. doi: 10.1186/s13023-0160543-7

2. Gatti RA, Berkel I, Boder E, Braedt G, Charmley P, Concannon $\mathrm{P}$, et al. Localization of an ataxia-telangiectasia gene to chromosome 11q22-23. Nature. (1988) 336:577-80. doi: 10.1038/ 336577a0

3. Boder E, Sedgwick RP. Ataxia-telangiectasia; a familial syndrome of progressive cerebellar ataxia, oculocutaneous telangiectasia and frequent pulmonary infection. Pediatrics. (1958) 21:526-54.

4. Lavin MF. Ataxia-telangiectasia: from a rare disorder to a paradigm for cell signalling and cancer. Nat Rev Mol Cell Biol. (2008) 9:75969. doi: $10.1038 / \mathrm{nrm} 2514$

5. Schroeder SA, Zielen S. Infections of the respiratory system in patients with ataxia-telangiectasia. Pediatr Pulmonol. (2014) 49:389-99. doi: 10.1002/ppul.22817

6. Nowak-Wegrzyn A, Crawford TO, Winkelstein JA, Carson KA, Lederman HM. Immunodeficiency and infections in ataxiatelangiectasia. J Pediatr. (2004) 144:505-11. doi: 10.1016/j.jpeds.2003. 12.046

7. Micol R, Ben Slama L, Suarez F, Le Mignot L, Beauté J, Mahlaoui $\mathrm{N}$, et al. Morbidity and mortality from ataxia-telangiectasia are associated with ATM genotype. J Allergy Clin Immunol. (2011) 128:382-9.e1. doi: 10.1016/j.jaci.2011.03.052

8. Mavrou A, Tsangaris GT, Roma E, Kolialexi A. The ATM gene and ataxia telangiectasia. Anticancer Res. (2008) 28:401-5.

9. Lavin MF, Kozlov S. ATM activation and DNA damage response. Cell Cycle. (2007) 6:931-42. doi: 10.4161/cc.6.8.4180 and SZ analyzed and interpreted the results. All authors contributed to revising the manuscript critically for important intellectual content and gave approval for the final version of the manuscript.

\section{FUNDING}

This study was funded by the SPARKS Charity (Grant Reference 14GOU01, London, England).

\section{ACKNOWLEDGMENTS}

We want to thank the SPARKS Charity (London, England) for their support and we thank our colleague Katrin Krug for technical assistance.

\section{SUPPLEMENTARY MATERIAL}

The Supplementary Material for this article can be found online at: https://www.frontiersin.org/articles/10.3389/fimmu. 2019.02785/full\#supplementary-material

Supplementary Figure 1 | $\mathrm{GFP}^{+}$donor cells in Atm-deficient mice after HSCT over time. The percentage of GFP ${ }^{+}$donor lymphocytes (A), CD3 ${ }^{+}$T-cells (B), $\mathrm{CD}^{+}{ }^{+} \mathrm{T}$-cells (C), CD8 ${ }^{+} \mathrm{T}$-cells (D), as well as naïve $\mathrm{CD} 4^{+} \mathrm{CD} 62 \mathrm{~L}^{\text {high }} \mathrm{CD} 44^{\text {low }}(\mathbf{E})$, and memory $\mathrm{CD} 4{ }^{+} \mathrm{CD} 62 \mathrm{~L}^{\text {low }} \mathrm{CD} 44^{\text {high }}(\mathbf{F}), \mathrm{CD}^{+} \mathrm{CD} 62 \mathrm{~L}^{\text {high }} \mathrm{CD} 44^{\text {low }}(\mathbf{G})$, and $\mathrm{CD}^{+}{ }^{+} \mathrm{CD} 62 \mathrm{~L}^{\text {low }} \mathrm{CD} 44^{\text {high }}(\mathbf{H})$ T-cells subpopulations measured in blood samples of transplanted $\mathrm{Atm}^{-/-}$mice $(\mathrm{n}=5) 6,12$, and 24 weeks after HSCT using flow cytometry. Data are represented as mean \pm SEM. ${ }^{*} P<0.05,{ }^{* *} P<0.01$,

${ }^{* * * *} P<0.001$ compared to 6 weeks, $\# \# P<0.01$, \#\#\# $P<0.001$ compared to 12 weeks.

10. Ball LG, Xiao W. Molecular basis of ataxia telangiectasia and related diseases. Acta Pharmacol Sin. (2005) 26:897907. doi: 10.1111/j.1745-7254.2005.00165.x

11. Oxelius VA, Berkel AI, Hanson LA. IgG2 deficiency in ataxia-telangiectasia. $N$ Eng J Med. (1982) 306:515-7. doi: 10.1056/NEJM198203043060905

12. Waldmann TA, Broder S, Goldman CK, Frost K, Korsmeyer SJ, Medici MA. Disorders of B cells and helper T cells in the pathogenesis of the immunoglobulin deficiency of patients with ataxia telangiectasia. J Clin Invest. (1983) 71:282-95. doi: 10.1172/JCI110768

13. Schubert R, Reichenbach J, Rose M, Zielen S. Immunogenicity of the seven valent pneumococcal conjugate vaccine in patients with ataxia-telangiectasia. Pediatr Infect Dis J. (2004) 23:26970. doi: 10.1097/01.inf.0000115737.35353.55

14. Paganelli R, Scala E, Scarselli E, Ortolani C, Cossarizza A, Carmini D, et al. Selective deficiency of CD4+/CD45RA + lymphocytes in patients with ataxiatelangiectasia. J Clin Immunol. (1992) 12:84-91. doi: 10.1007/BF00918137

15. Schubert R, Reichenbach J, Zielen S. Deficiencies in CD4+ and CD8+ T cell subsets in ataxia telangiectasia. Clin Exp Immunol. (2002) 129:12532. doi: 10.1046/j.1365-2249.2002.01830.x

16. Fiorilli M, Carbonari M, Crescenzi M, Russo G, Aiuti F. T-cell receptor genes and ataxia telangiectasia. Nature. (1985) 313:186. doi: 10.1038/313186a0

17. Carbonari M, Cherchi M, Paganelli R, Giannini G, Galli E, Gaetano C, et al. Relative increase of $\mathrm{T}$ cells expressing the gamma/delta rather than the alpha/beta receptor in ataxia-telangiectasia. N Engl J Med. (1990) 322:736. doi: 10.1056/NEJM199001113220201

18. Driessen GJ, Ijspeert H, Weemaes CM, Haraldsson Á, Trip M, Warris A, et al. Antibody deficiency in patients with ataxia telangiectasia is caused by disturbed B- and T-cell homeostasis and reduced immune repertoire diversity. J Allergy Clin Immunol. (2013) 131:1367-75.e9. doi: 10.1016/j.jaci.2013.01.053

19. Bredemeyer AL, Huang CY, Walker LM, Bassing CH, Sleckman BP. Aberrant $\mathrm{V}(\mathrm{D}) \mathrm{J}$ recombination in ataxia telangiectasia mutated-deficient lymphocytes 
is dependent on nonhomologous DNA end joining. J Immunol. (2008) 181:2620-5. doi: 10.4049/jimmunol.181.4.2620

20. Pan-Hammarström Q, Dai S, Zhao Y, van Dijk-Härd IF, Gatti RA, BørresenDale AL, et al. ATM is not required in somatic hypermutation of $\mathrm{VH}$, but is involved in the introduction of mutations in the switch mu region. J Immunol. (2003) 170:3707-16. doi: 10.4049/jimmunol.170.7.3707

21. Lumsden JM, McCarty T, Petiniot LK, Shen R, Barlow C, Wynn TA, et al. Immunoglobulin class switch recombination is impaired in Atm-deficient mice. J Exp Med. (2004) 200:1111-21. doi: 10.1084/jem.20041074

22. Bagley J, Cortes ML, Breakefield XO, Iacomini J. Bone marrow transplantation restores immune system function and prevents lymphoma in Atm-deficient mice. Blood. (2004) 104:572-8. doi: 10.1182/blood-2003-12-4226

23. Pietzner J, Merscher BM, Baer C, Duecker RP, Eickmeier O, Fußbroich D, et al. Low-dose irradiation prior to bone marrow transplantation results in ATM activation and increased lethality in Atm-deficient mice. Bone Marrow Transplant. (2016) 51:560-7. doi: 10.1038/bmt.2015.334

24. Pietzner J, Baer C, Duecker RP, Merscher MB, Satzger-Prodinger C, Bechmann I, et al. Bone marrow transplantation improves the outcome of Atm-deficient mice through the migration of ATM-competent cells. Hum Mol Genet. (2013) 22:493-507. doi: 10.1093/hmg/dds448

25. Bakhtiar S, Woelke S, Huenecke S, Kieslich M, Taylor AM, Schubert R, et al. Pre-emptive allogeneic hematopoietic stem cell transplantation in ataxia telangiectasia. Front Immunol. (2018) 9:2495. doi: 10.3389/fimmu.2018.02495

26. Barlow C, Hirotsune S, Paylor R, Liyanage M, Eckhaus M, Collins F, et al. Atm-deficient mice: a paradigm of ataxia telangiectasia. Cell. (1996) 86:15971. doi: 10.1016/S0092-8674(00)80086-0

27. Okabe M, Ikawa M, Kominami K, Nakanishi T, Nishimune Y. 'Green mice' as a source of ubiquitous green cells. FEBS Lett. (1997) 407:3139. doi: 10.1016/S0014-5793(97)00313-X

28. Slack J, Albert MH, Balashov D, Belohradsky BH, Bertaina A, Bleesing J, et al. Outcome of hematopoietic cell transplantation for DNA doublestrand break repair disorders. J Allergy Clin Immunol. (2018) 141:322328.e10. doi: 10.1016/j.jaci.2017.02.036

29. Ussowicz M, Wawrzyniak-Dzierzek E, Mielcarek-Siedziuk M, Salamonowicz M, Fraczkiewicz J, Rybka B, et al. Allogeneic stem cell transplantation after fanconi anemia conditioning in children with ataxia-telangiectasia results in stable T cell engraftment and lack of infections despite mixed chimerism. Biol Blood Marrow Transplant. (2018) 24:2245-9. doi: 10.1016/j.bbmt.2018.07.001

30. Ghosh S, Schuster FR, Binder V, Niehues T, Baldus SE, Seiffert P, et al. Fatal outcome despite full lympho-hematopoietic reconstitution after allogeneic stem cell transplantation in atypical ataxia telangiectasia. J Clin Immunol. (2012) 32:438-40. doi: 10.1007/s10875-012-9654-7

31. Pollard JM, Reboucas JS, Durazo A, Kos I, Fike F, Panni M, et al. Radioprotective effects of manganese-containing superoxide dismutase mimics on ataxia-telangiectasia cells. Free Radic Biol Med. (2009) 47:25060. doi: 10.1016/j.freeradbiomed.2009.04.018

32. Carney EF, Srinivasan V, Moss PA, Taylor AM. Classical ataxia telangiectasia patients have a congenitally aged immune system with high expression of CD95. J Immunol. (2012) 189:261-8. doi: 10.4049/jimmunol.1101909

33. Boyman O, Létourneau S, Krieg C, Sprent J. Homeostatic proliferation and survival of naïve and memory T cells. Eur J Immunol. (2009) 39:208894. doi: 10.1002/eji.200939444

34. van den Broek T, Borghans JAM, van Wijk F. The full spectrum of human naive $\mathrm{T}$ cells. Nat Rev Immunol. (2018) 18:363-73. doi: 10.1038/s41577-018-0001-y

35. Sallusto F, Geginat J, Lanzavecchia A. Central memory and effector memory T cell subsets: function, generation, and maintenance. Ann Rev Immunol. (2004) 22:745-63. doi: 10.1146/annurev.immunol.22.012703.104702

36. Tough DF, Sprent J. Turnover of naive- and memory-phenotype T cells. J Exp Med. (1994) 179:1127-35. doi: 10.1084/jem.179.4.1127

37. Ito K, Hirao A, Arai F, Matsuoka S, Takubo K, Hamaguchi I, et al. Regulation of oxidative stress by ATM is required for self-renewal of haematopoietic stem cells. Nature. (2004) 431:997-1002. doi: 10.1038/nature02989

38. Giovannetti A, Mazzetta F, Caprini E, Aiuti A, Marziali M, Pierdominici $\mathrm{M}$, et al. Skewed T-cell receptor repertoire, decreased thymic output, and predominance of terminally differentiated $\mathrm{T}$ cells in ataxia telangiectasia. Blood. (2002) 100:4082-9. doi: 10.1182/blood-2002-03-0976
39. Micheli R, Pirovano S, Calandra G, Valotti M, Plebani A, Albertini A, et al. Low thymic output and reduced heterogeneity of alpha/beta, but not gamma/delta, $\mathrm{T}$ lymphocytes in infants with ataxiatelangiectasia. Neuropediatrics. (2003) 34:165-7. doi: 10.1055/s-200341280

40. Matei IR, Gladdy RA, Nutter LMJ, Canty A, Guidos CJ, Danska JS. ATM deficiency disrupts Tcra locus integrity and the maturation of CD4+CD8+ thymocytes. Blood. (2007) 109:1887-96. doi: 10.1182/blood-2006-05020917

41. Vacchio MS, Olaru A, Livak F, Hodes RJ. ATM deficiency impairs thymocyte maturation because of defective resolution of $\mathrm{T}$ cell receptor alpha locus coding end breaks. Proc Natl Acad Sci USA. (2007) 104:63238. doi: 10.1073/pnas.0611222104

42. Ito K, Takubo K, Arai F, Satoh H, Matsuoka S, Ohmura M, et al. Regulation of reactive oxygen species by Atm is essential for proper response to DNA double-strand breaks in lymphocytes. J Immunol. (2007) 178:10310. doi: 10.4049/jimmunol.178.1.103

43. Bjorkdahl O, Barber KA, Brett SJ, Daly MG, Plumpton C, Elshourbagy $\mathrm{NA}$, et al. Characterization of CC-chemokine receptor 7 expression on murine $\mathrm{T}$ cells in lymphoid tissues. Immunology. (2003) 110:1709. doi: 10.1046/j.1365-2567.2003.01727.x

44. Patenaude J, D’Elia M, Hamelin C, Garrel D, Bernier J. Burn injury induces a change in T cell homeostasis affecting preferentially CD4+ T cells. J Leukoc Biol. (2005) 77:141-50. doi: 10.1189/jlb.0703314

45. Campbell A, Krupp B, Bushman J, Noble M, Pröschel C, Mayer-Pröschel M. A novel mouse model for ataxia-telangiectasia with a $\mathrm{N}$-terminal mutation displays a behavioral defect and a low incidence of lymphoma but no increased oxidative burden. Hum Mol Genet. (2015) 24:633149. doi: $10.1093 / \mathrm{hmg} / \mathrm{ddv} 342$

46. Di Siena S, Campolo F, Gimmelli R, Di Pietro C, Marazziti D, Dolci S, et al. Atm reactivation reverses ataxia telangiectasia phenotypes in vivo. Cell Death Dis. (2018) 9:314. doi: 10.1038/s41419-018-0357-8

47. Westbrook AM, Schiestl RH. Atm-deficient mice exhibit increased sensitivity to dextran sulfate sodium-induced colitis characterized by elevated DNA damage and persistent immune activation. Cancer Res. (2010) 70:187584. doi: 10.1158/0008-5472.CAN-09-2584

48. Heining C, Spyridonidis A, Bernhardt E, Schulte-Monting J, Behringer D, Grullich C, et al. Lymphocyte reconstitution following allogeneic hematopoietic stem cell transplantation: a retrospective study including 148 patients. Bone Marrow Transplant. (2007) 39:613-22. doi: 10.1038/sj.bmt.1705648

49. Krenger W, Blazar BR, Holländer GA. Thymic T-cell development in allogeneic stem cell transplantation. Blood. (2011) 117:676876. doi: 10.1182/blood-2011-02-334623

50. Ogonek J, Kralj Juric M, Ghimire S, Varanasi PR, Holler $\mathrm{E}$, Greinix $\mathrm{H}$, et al. Immune reconstitution after allogeneic hematopoietic stem cell transplantation. Front Immunol. (2016) 7:507. doi: 10.3389/fimmu.2016.00507

51. Woelke S, Valesky E, Bakhtiar S, Pommerening H, Pfeffermann LM, Schubert $\mathrm{R}$, et al. Treatment of granulomas in patients with ataxia telangiectasia. Front Immunol. (2018) 9:2000. doi: 10.3389/fimmu.2018.02000

52. Perlingeiro Beltrame M, Malvezzi M, Bonfim C, Covas DT, Orfao A, Pasquini R. Immune reconstitution in patients with Fanconi anemia after allogeneic bone marrow transplantation. Cytotherapy. (2014) 16:97689. doi: 10.1016/j.jcyt.2014.02.015

Conflict of Interest: The authors declare that the research was conducted in the absence of any commercial or financial relationships that could be construed as a potential conflict of interest.

Copyright (C) 2019 Duecker, Baer, Buecker, Huenecke, Pfeffermann, Modlich, Bakhtiar, Bader, Zielen and Schubert. This is an open-access article distributed under the terms of the Creative Commons Attribution License (CC BY). The use, distribution or reproduction in other forums is permitted, provided the original author(s) and the copyright owner(s) are credited and that the original publication in this journal is cited, in accordance with accepted academic practice. No use, distribution or reproduction is permitted which does not comply with these terms. 